\title{
Characterization and Quantification of Postharvest Losses of Apple Fruit Stored under Commercial Conditions
}

\author{
Luiz C. Argenta \\ Epagri, Estação Experimental de Caçador. C.P. 501, Caçador, SC \\ 89501-032 Brazil
}

Sérgio T. de Freitas

Embrapa Semiárido, Rodovia BR-428, Km 152, C.P. 23, Petrolina, PE 56302-970 Brazil

James P. Mattheis

U.S. Department of Agriculture, Agricultural Research Service Tree Fruit Research Laboratory, 1104 N. Western Avenue, Wenatchee, WA 98801

Marcelo J. Vieira

Fischer S/A Agroindústria, Rodovia SC 355, Km 24, Fraiburgo, SC 89.580-000 Brazil

\section{Claudio Ogoshi}

Epagri, Estação Experimental de Caçador. C.P. 501, Caçador, SC 89501-032 Brazil

Additional index words. fruit rot, Malus $\times$ domestica Borkh, physiological disorders, postharvest diseases, quality, 1-MCP

Abstract. The objectives of this study were to characterize and quantify postharvest losses of apples under commercial conditions in Santa Catarina state, Brazil. Two experiments were conducted using 'Gala' and 'Fuji' apples. The first experiment was to characterize and quantify the most important causes of loss of fruit treated or not treated with 1-methylcyclopropene (1-MCP) then held in controlled atmosphere (CA) storage. This experiment was conducted in commercial storage facilities from 2007 to 2010. In each year, 10 samples of $\approx 380 \mathrm{~kg}$ each for 'Gala' and $400 \mathrm{~kg}$ each for 'Fuji' were collected from bins of commercially harvested fruit from each of 15 'Gala' and 17 'Fuji' orchards. Half of the samples from each orchard were treated with 1-MCP at harvest. Fruit were stored in $\mathrm{CA}$, at $0.7^{\circ} \mathrm{C}$, for 150 to 300 days. After storage, one subsample of 100 disorder-free apples were selected from each sample and held at $22{ }^{\circ} \mathrm{C}$ for 7 days to simulate shelf-life conditions. The fruit were analyzed after $\mathrm{CA}$ storage and shelf life for the incidence of disorders. The second experiment was conducted in 2011 to identify the main fungi causing decay during storage. In this study, apples were stored in 10 commercial CA storage rooms at $0.7^{\circ} \mathrm{C}$ for 180 to 240 days. After storage, fruit with decay symptoms were collected at the commercial sorting line. A total of 10 samples of 100 decayed apples were taken throughout the sorting period for each cultivar and storage room. The fungal decays were identified by visual symptoms on each fruit. Total apple losses during storage varied from $3.9 \%$ to $12.1 \%$ for 'Gala' and $6.6 \%$ to $8.4 \%$ for 'Fuji', depending on the year and 1-MCP treatment. During storage, deterioration caused by fungal decay was $\approx \mathbf{6 0} \%$ and $\mathbf{8 0 \%}$ of total losses for 'Gala' and 'Fuji', respectively. During shelf life, additional losses caused by fungal decay ranged from $8.4 \%$ to $17.6 \%$ for 'Gala' and $\mathbf{1 2 . 4 \%}$ to $\mathbf{2 7 . 2 \%}$ for 'Fuji', depending on the year. Senescent breakdown and superficial scald were the major physiological disorders. 1-MCP treatment had no effect on losses due to decay. Bull's-eye rot, blue mold, gray mold, and alternaria rot were the most prevalent fungal decay symptoms, accounting for $52 \%, 27 \%, 9 \%$ and $10 \%$ of 'Gala' losses and $42 \%, 25 \%, 18 \%$ and $5 \%$ of 'Fuji' losses, respectively. Sources of variability for losses among years and orchards is discussed.

Although the efficiency of food production worldwide has increased over the years, studies estimate approximately onethird of all food and $45 \%$ to $55 \%$ of all fruit and vegetables produced worldwide are lost or wasted, corresponding to 1.2 to 2 billion tons of food loss every year (Porat et al., 2018). For apple fruit, estimates include
$8.6 \%$ fresh apples lost at retail and $20 \%$ lost at the consumer level in the United States (Buzby et al., 2011). These estimates suggest a highly inefficient use of natural resources such as land, water, and energy for apple production (Buzby et al., 2011). Therefore, minimizing postharvest apple fruit losses is more sustainable than increasing production to compensate for these losses (Kader, 2005).

Factors contributing to loss and waste of fruit after harvest include development of fungal decay, physiological disorders, mechanical injuries, as well as deterioration of appearance, texture, and flavor that lead to consumer dissatisfaction (Kader, 2005).

Studies have shown that many fungal species can cause decay in apple fruit after harvest (Sutton et al., 2014), although only a few lead to fruit losses under commercial conditions (Sugar, 2002). The likelihood of fungal decay depends on apple genotype, pre- and postharvest management practices, and environmental conditions (Cameldi et al., 2016; Spotts et al., 2009; Sugar, 2002; Sutton et al., 2014). Postharvest fungal decay results mainly from preharvest latent infection or wound infection that can occur either before or after harvest (Wenneker and Thomma, 2020). Latent infections occur through the intact fruit tissue or natural skin openings such as lenticels, whereas wound infection occurs through wounds caused by insects, hail, physiological disorders, and mechanical damage (Prusky et al., 2013; Sugar, 2002). Some of the most important fungi causing postharvest apple decay, such as Botrytis spp. Penicillium spp., Mucor spp., and Monilia spp., infect the fruit through wounded tissues, whereas others such as Neofabraea spp., Colletotrichum spp., Alternaria spp., Fusarium spp., Sphaeropsis pyriputrescens, and Phacidiopycnis washingtonensis can infect the fruit by latent infections (Kim and Xiao, 2006, 2008; Sugar, 2002; Wenneker and Thomma, 2020). Identification of the most important fungi causing decay can help develop effective control approaches considering that each pathogen has a different response to environmental and crop management conditions (Sugar, 2002). Apple postharvest losses caused by fungi have been reported to range from $0.25 \%$ to $25 \%$, depending on orchard and postharvest fungicide treatments (Kim and Xiao, 2008); $2 \%$ to $40 \%$, depending on the storage duration and year (Neri et al., 2009; Neuwald and Kittemann, 2016); $0 \%$ to $70 \%$, depending on harvest maturity, year, and growing region (Breeyen et al., 2020; Cameldi et al., 2016).

Apples can develop many physiological disorders after harvest that are expressed by skin and or flesh browning, blackening or cracking, mealy texture, corking, shriveling, and other symptoms. The incidence of physiological disorders in apples is highly regulated by the genotype and environmental conditions before and after harvest (Watkins and Mattheis, 2019). These disorders have been reported to potentially cause losses higher than $80 \%$ of total stored fruit (DeEll and EhsaniMoghaddam, 2013; DeLong et al., 2004; Koushesh Saba and Watkins, 2020; Lee et al., 2016; Mattheis et al., 2017). Although studies have attempted to elucidate the factors and mechanisms regulating physiological disorders in apples, there is still limited knowledge to develop efficient prediction approaches as a means to reduce losses caused by these disorders (Watkins and Mattheis, 2019). 
Sanitation and storage technologies have been greatly improved to reduce postharvest apple losses due to disorders (Adaskaveg et al., 2002; Bai et al., 2009; Watkins, 2008). These technologies have also been used to extend the duration apples are available at retail throughout the year, stimulating fruit consumption and production. However, longer storage periods potentially result in higher incidence of decay and physiological disorders (DeEll et al., 2007; DeLong et al., 2004; Neri et al., 2009). Although effective for slowing fruit ripening and preventing development of some physiological disorders, the use of CA storage with low $\mathrm{pO}_{2}$ and high $\mathrm{pCO}_{2}$ and the inhibition of ethylene responses by 1 -methylcyclopropene (1-MCP) may not be efficient to prevent fungal decay as these technologies have no direct effect on fungi that cause decay (Adaskaveg et al., 2002; Sugar, 2002; Watkins, 2008).

1-MCP inhibits apple fruit ripening by competing with ethylene in the ethylene response pathway (Mattheis, 2008; Watkins, 2008). The impact 1-MCP has on the fungal decay process have been variable. Studies have shown that 1-MCP may decrease (Cameldi et al., 2016; DeEll and Ehsani-Moghaddam, 2013; Gago et al., 2015; Li et al., 2017; Saftner et al., 2003; Zhou et al., 2016) or increase (Janisiewicz et al., 2003; Leverentz et al., 2003) decay incidence in apples, whereas other studies have shown no effect on decay (DeEll et al., 2007; DeLong et al., 2004; Errampalli et al., 2012). Similarly, 1-MCP can inhibit physiological disorders such as superficial scald, senescent breakdown, and bitter pit while exacerbating others such as carbon dioxide injury, leather blotch, and diffuse skin browning (DeEll et al., 2003; Mattheis, 2008; Watkins, 2008; Watkins and Mattheis, 2019). Considering that $1-\mathrm{MCP}$ is routinely applied by apple storage operators worldwide, further investigation is important to develop information regarding its effect on fungal decay and physiological disorders, as well as postharvest apple losses under commercial conditions.

Although numerous studies conducted under controlled laboratory conditions have shown the potential amount of apple losses during and after storage, studies carried out to characterize and quantify apple losses under large-scale commercial storage conditions are lacking. These studies can help guide future research to control losses and ultimately improve efficiency of the apple fruit industry.

Received for publication 10 Feb. 2021. Accepted for publication 23 Mar. 2021.

Published online 3 May 2021.

We thank Daisuke Shirayama, Roberto Stanke, Francielle de Souza, Simone Werner, and Fischer S/A Agroindustry for their excellent support of this project.

Financial support for this research received from AgroFresh, Inc.

L.C.A. is the corresponding author. E-mail: argenta@epagri.sc.gov.br

This is an open access article distributed under the CC BY-NC-ND license (https://creativecommons. org/licenses/by-nc-nd/4.0/).
The objectives of this study were to characterize and quantify sources of postharvest losses of apples stored under commercial conditions with and without the use of 1-MCP.

\section{Material and Methods}

Two experiments were conducted using 'Gala' and 'Fuji' apples grown in Santa Catarina State, Brazil. The first experiment was performed from 2007 through 2010 to characterize and quantify apple losses during long-term CA storage and shelf life periods. The second experiment was conducted in 2011 to identify the main pathogenic fungi responsible for apple fruit decay.

\section{Expt. 1 Characterization and quantification of apple losses}

Fruit samples. Twenty samples of apples were collected from harvested bins from each of 15 'Gala' and 17 'Fuji' orchards (grower lots) within $24 \mathrm{~h}$ after harvest each year from 2007 to 2010. These orchards represent appleproducing areas in southern Brazil. Commercial harvest was accomplished during a period of $15 \mathrm{~d}$ within the commercial harvest window of fruit intended for long-term storage. Fruit were not treated with fungicide or sanitizers after harvest. Each sample had $\approx 380 \mathrm{~kg}$ $(\approx 3140$ fruit $)$ of 'Gala' or $\approx 400 \mathrm{~kg}(\approx 2963$ fruit) of 'Fuji'. One subsample of 10 apples from each bin (200 apples per cultivar and orchard) was assessed for fruit firmness at harvest. The remaining fruit from each sample $(\approx 3130$ 'Gala' or 2953 'Fuji') were assessed $24 \mathrm{~h}$ after long-term CA storage. One subsample of 100 apples without visual symptoms of fungal decay or physiological disorders with medium size representative of each bin was taken from each bin $24 \mathrm{~h}$ after long-term CA storage for assessment after 7-d shelf-life simulation. Therefore, 2560 bin-samples (4 years $\times 32$ orchards per year $\times 20$ bin-samples per orchard) were analyzed after CA storage and 2560 samples with 100 apples were analyzed after exposing the fruit to shelf life conditions.

1-MCP treatment. For each year, orchard and cultivar, half of the 20 bin-samples were exposed to 1-MCP for $24 \mathrm{~h}$, within $60 \mathrm{~h}$ after harvest, in commercial storage rooms following commercial recommendation for the SmartFresh System (AgroFresh Inc., Spring House, PA). The amount of SmartFresh used was proportional to each storage room volume, targeting the label rate in Brazil for apples between 25 and $50 \mu \mathrm{mol} \cdot \mathrm{m}^{-3}$. The untreated control fruit were held for $24 \mathrm{~h}$ in a separate storage room filled or partially loaded with apple fruit. Temperature in storage rooms for controls and 1-MCP treatments were identical. After the 1-MCP treatment, each room was opened and vented for at least $2 \mathrm{~h}$. Then the control fruit were moved to the same room containing the 1-MCP treated fruit.

Fruit storage and shelf-life conditions. Fruit cooling was initiated within $24 \mathrm{~h}$ after harvest and the fruit temperature reached $\approx 4{ }^{\circ} \mathrm{C}$ within $36 \mathrm{~h}$ and $0.5^{\circ} \mathrm{C}$ to $0.8^{\circ} \mathrm{C}$ within $96 \mathrm{~h}$ after harvest. Fruit from each orchard were held in separate commercial CA rooms at $0.5^{\circ} \mathrm{C}$ to $0.8^{\circ} \mathrm{C}$, for 150 to $270 \mathrm{~d}$ for ' $\mathrm{Gala}$ ' and 170 to $300 \mathrm{~d}$ for 'Fuji'. Therefore, a total of 32 commercial storage rooms were used each year, and each storage room held fruit from one orchard. Each storage room was loaded with the 20 samples for this study plus 500 to 800 tons of apples for marketing. Concentration of $\mathrm{O}_{2}$ was maintained at $1.5 \pm 0.2$ $\mathrm{kPa}$ for both cultivars, whereas $\mathrm{CO}_{2}$ concentration was $2.5 \pm 0.2 \mathrm{kPa}$ for 'Gala' and $<0.5$ $\mathrm{kPa}$ for 'Fuji'. $\mathrm{pO}_{2}$ was reduced to $4 \mathrm{kPa}$ by $\mathrm{N}_{2}$ injection in $\approx 20 \mathrm{~h}$ and to $1.5 \mathrm{kPa}$ by fruit respiration in 4 to $5 \mathrm{~d}$ for both cultivars. The injection of $\mathrm{N}_{2}$ in 'Gala' storage rooms was within $12 \mathrm{~h}$ after 1-MCP treatment. Establishment of CA was delayed 3 weeks for 'Fuji' to avoid $\mathrm{CO}_{2}$ injury. After $\mathrm{CA}$ storage, fruit were held in air $\left(\approx 1^{\circ} \mathrm{C}\right)$ for $24 \mathrm{~h}$ before analyses. For shelf-life simulation, fruit were held $7 \mathrm{~d}$ in a $100 \mathrm{~m}^{3}$ room at $22 \pm 1^{\circ} \mathrm{C}$.

Assessment of fruit losses during storage and shelf life. After CA storage, all apples from each bin-sample were manually segregated by presence or absence of any visual disorder. Disorders were identified as fungal decay or physiological disorders such as shrivel, superficial scald, low calcium disorders (bitter pit and blotch pit), or senescent breakdown (skin cracking and or skin discoloration). Only the most prominent disorder was recorded for each fruit. For instance, if superficial scald and fungal decay were both present, the disorder affecting the largest amount of skin area was recorded. This approach allowed calculating the total amount (\%) of apple loss by adding the percentage of fruit affected by each disorder. The percentage of apples affected by each disorder in each bin-sample was calculated by multiplying the total weight of apples with a disorder by 100 and dividing by the total fruit weight of each respective bin-sample. Severely decayed fruit were replaced by a healthy fruit with similar size for weighing.

After shelf life, apples were visually assessed for external disorders as described earlier as well as for flesh firmness and internal disorders including flesh browning (diffuse light browning in the cortex), $\mathrm{CO}_{2}$ injury (well-defined, dark, brown areas in the flesh), core browning and moldy core rot. After shelf life, all disorders present were recorded for each fruit. This approach does not allow calculating the total amount $(\%)$ of apple loss by adding the percentage of fruit affected by each disorder. The percentage of apples with each disorder was calculated by multiplying the number of fruit for each disorder by 100 and dividing by the total number of fruit in each sample (100).

Flesh firmness was determined on a peeled equatorial region, between exposed and shaded sides, using a penetrometer with a standard Effegi 11-mm diameter probe mounted on a motorized drive (Güss, Strand, South Africa). The physiological disorders superficial scald, flesh browning, bitter pit, blotch pit, core browning, and $\mathrm{CO}_{2}$ injury were identified by visual symptoms as previously described (Pierson et al., 1971; Watkins and Mattheis, 2019). 


\section{Expt. 2: Identification of apple fruit decay symptoms}

'Gala' and 'Fuji' apples harvested in 2011 were stored in commercial CA conditions as described for Expt. 1. Fruit from 10 commercial storage rooms per cultivar were collected after 180 to $240 \mathrm{~d}$ in storage. In each storage room, 10 samples of 100 apples with visible decay symptoms were randomly picked at the pre-size sorting line throughout the sorting period for the whole room. Apples were then grouped by the most prominent decaycausing pathogen, identified by the visual symptoms, following previous descriptions (Pierson et al., 1971; Snowdon, 1990; Sutton et al., 2014). Pathogen incidence was calculated by multiplying the number of fruit with each pathogen symptom by 100 and dividing by the total number of fruit per sample (100).

\section{Weather data}

Temperature, relative humidity, and rainfall data were obtained from a weather station of Santa Catarina Agricultural Research and Extension Corporation located in the midwest of Santa Catarina State. Temperature $\left({ }^{\circ} \mathrm{C}\right)$ and relative humidity (\%) were measured hourly using a chart recorder thermo-hygrograph (Wilh. Lambrecht, Einbeck, Germany). Temperatures were also recorded daily at 9:00 $\mathrm{AM}, 3: 00 \mathrm{PM}$, and 9:00 PM using a mercury thermometer (Incoterm, Porto Alegre, RS, Brazil). The rainfall (millimeters) was recorded daily at 9:00 $\mathrm{AM}, 3: 00 \mathrm{PM}$, and 9:00 PM using Ville de Paris rain gauge (Hidromec, RJ, Brazil). Accumulated rainfall was obtained by adding daily rainfall for the fruit growing period (from full bloom to the harvest window) and for the 2 months before the harvest (including the harvest window) of each year and cultivar. Daily mean temperatures were used to obtain the mean temperature for each fruit production year. The number of hours below $7.2^{\circ} \mathrm{C}$ was computed for the winter period (from June to September) of each preceding harvest year.

\section{Statistical analysis}

Expt. 1 was conducted as a $4 \times 2$ factorial (production year $\times 1-\mathrm{MCP}$ treatment) for each cultivar. Expt. 2 was conducted as a $2 \times$ 8 factorial (cultivar $\times$ pathogen). Both experiments were carried out in randomized complete block design with 10 bin-samples or ten 100-fruit samples per replication. Data without normal distribution were transformed by $\operatorname{arc} . \sin \sqrt{\mathrm{Y} / 100}$ before analysis of variance using SAS software (SAS Institute Inc., Cary, $\mathrm{NC})$. Mean values were compared using Tukey's test $(P<0.05)$. The variability of apple losses among orchards (storage rooms) was described by percentiles of orchards in classes (\%) of apple loss presented as boxplots. Correlation analysis of apple losses and flesh firmness after shelf life was accomplished using Pearson product-moment

\section{Results}

\section{Losses during CA storage}

There was no interaction between production year and 1-MCP treatment on disorder incidence after CA storage for either cultivar (Tables 1 and 2). Production year had a significant effect on decay incidence, senescent breakdown, shrivel, and total losses for 'Gala' and on the incidence of bitter pit and blotch pit for 'Fuji'.

The highest total loss of 'Gala' was observed in 2007, reaching $12.1 \%$, whereas losses between $3.9 \%$ to $5.6 \%$ were observed in the other years. In 3 of 4 years, the incidence of decay was the major cause of 'Gala' loses, representing $56 \%$ to $81 \%$ of total loses followed by senescent breakdown, shrivel and low $\mathrm{Ca}$ disorders. In 2008, the incidence of decay was low, and senescent breakdown was the major cause of 'Gala' loss. Treatment with 1-MCP did not affect 'Gala' losses during CA storage. Apple losses due to shrivel and low Ca disorders were below $1 \%$ for both cultivars.

The total 'Fuji' loss was similar in all 4 years and varied from $8.4 \%$ in controls to $6.6 \%$ in 1-MCP-treated fruit. This reduction of 'Fuji' losses for 1-MCP-treated fruit was associated with reduced superficial scald incidence. In all 4 years, the incidence of decay was the major cause of 'Fuji' losses, representing 75\% to $85 \%$ of total losses, followed by superficial scald, shrivel, and low Ca disorders.

Apple losses during and after CA storage varied among orchards within each year in both cultivars (Fig. 1). The variability among orchards was higher in 2007 than 2008-10 for 'Gala' and was slightly higher in 2007 and 2009 compared with 2008 and 2010 for
'Fuji'. 'Gala' total loss in 2007 ranged from $6.1 \%$ to $18 \%$ for $50 \%$ of the orchards, and between $2.2 \%$ and $26.5 \%$ for $90 \%$ of the orchards, whereas in 2009 , total 'Gala' losses ranged from $1.6 \%$ to $5.3 \%$ for $50 \%$ of the orchards, and from $1.2 \%$ to $7.1 \%$ for $90 \%$ of the orchards (Fig. 1A). In 2007 the total losses of 'Fuji' ranged from $4.1 \%$ to $10.3 \%$ for $50 \%$ of the orchards, and between $2.4 \%$ and $15 \%$ for $90 \%$ of the orchards, while in 2009 , the total losses ranged from $5.2 \%$ to $9.3 \%$ for $50 \%$ of the orchards, and between $4.7 \%$ and $11.6 \%$ for $90 \%$ of the orchards (Fig. 1B).

\section{Losses during shelf life}

After the shelf-life period, there was no interaction between production year and 1MCP treatment for either cultivar (Tables 3 and 4). Decay was the major cause of losses during shelf life. Treatment with 1-MCP did not affect development of decay in either cultivar but reduced the second major cause of loss for each cultivar with 'Gala' flesh browning and 'Fuji' superficial scald.

The highest incidence of decay in 'Gala' apples was observed in 2007 and 2010 with losses of $17.6 \%$ and $17.1 \%$, whereas the lowest incidence was in 2008 and 2009 with losses of $8.4 \%$ and $9.4 \%$, respectively. The incidence of 'Fuji' decay was highest (27.2\%) in 2010 and ranged from $12.4 \%$ to $17.5 \%$ in the other years.

The incidence of flesh browning in 'Gala' was highest in 2007 and 2010 and lowest in 2009 , ranging from $4.8 \%$ to $15 \%$ depending on year and 1-MCP treatment. Shrivel in 'Gala' apples was unaffected by production year or 1-MCP treatment, ranging from $0.0 \%$ to $1.7 \%$. Low-Ca disorder (bitter pit and blotch pit) incidence was highest in 2009, reaching $0.5 \%$, and not detected in 2007 .

Superficial scald incidence for 'Fuji' was similar in all years and was reduced by 1MCP treatment from $12.7 \%$ in nontreated fruit to $0.7 \%$ in treated fruit. Core rot incidence was unaffected by production year or 1-MCP treatment, ranging from $1.6 \%$ to $3.0 \%$. Shrivel and core browning incidence in 'Fuji' was highest in 2010 and was reduced by 1-MCP treatment. The incidence of Ca-related disorders was highest in 2010, reaching $1.4 \%$ and was unaffected by 1-MCP treatment, whereas

Table 1. Incidence (\%) of fungal decay and physiological disorders on 'Gala' apple fruit after controlled atmosphere storage. Fruit were assessed $24 \mathrm{~h}$ after removal from storage.

\begin{tabular}{|c|c|c|c|c|c|c|c|c|c|c|c|c|c|c|}
\hline \multirow[b]{2}{*}{ Yr } & \multicolumn{3}{|c|}{ Fungal decay } & \multicolumn{3}{|c|}{ Senescent breakdown } & \multicolumn{3}{|c|}{ Shrivel } & \multicolumn{2}{|c|}{ Ca-deficiency disorders } & \multicolumn{3}{|c|}{ Total } \\
\hline & Control & 1-MCP & Avg & Control & 1-MCP & Avg & Control & 1-MCP & Avg & Control & 1-MCP & Control & 1-MCP & Avg \\
\hline 2007 & 7.4 & 6.1 & $6.8 \mathrm{a}$ & 4.8 & 3.4 & $4.1 \mathrm{a}$ & 1.12 & 0.55 & $0.83 \mathrm{a}$ & 0.35 & 0.36 & 13.7 & 10.5 & $\overline{12.1 \mathrm{a}}$ \\
\hline 2008 & 1.4 & 1.7 & $1.6 \mathrm{~b}$ & 4.1 & 3.3 & $3.7 \mathrm{a}$ & 0.07 & 0.01 & $0.04 \mathrm{~b}$ & 0.22 & 0.38 & 5.8 & 5.4 & $5.6 \mathrm{~b}$ \\
\hline 2009 & 3.2 & 3.2 & $3.2 \mathrm{~b}$ & 0.3 & 0.3 & $0.3 \mathrm{~b}$ & 0.10 & 0.03 & $0.06 \mathrm{~b}$ & 0.40 & 0.25 & 4.0 & 3.9 & $3.9 \mathrm{~b}$ \\
\hline 2010 & 3.2 & 3.0 & $3.1 \mathrm{~b}$ & 1.0 & 0.6 & $0.8 \mathrm{~b}$ & 0.02 & 0.01 & $0.02 \mathrm{~b}$ & 0.25 & 0.18 & 4.5 & 3.8 & $4.2 \mathrm{~b}$ \\
\hline Average & 3.8 & 3.5 & & 2.6 & 1.8 & & 0.33 & 0.15 & & 0.30 & 0.29 & 7.1 & 6.0 & \\
\hline Year & \multicolumn{3}{|c|}{$* * *$} & \multicolumn{2}{|c|}{$* * *$} & & \multicolumn{2}{|c|}{$* *$} & & \multicolumn{2}{|c|}{ NS } & \multicolumn{2}{|c|}{$* * *$} & \\
\hline Treatment & \multicolumn{2}{|c|}{ NS } & & \multicolumn{2}{|c|}{ NS } & & \multicolumn{2}{|c|}{ NS } & & \multicolumn{2}{|c|}{ NS } & \multicolumn{2}{|c|}{ NS } & \\
\hline Year $\times$ treatment & \multicolumn{3}{|c|}{ NS } & \multicolumn{2}{|c|}{ NS } & & \multicolumn{2}{|c|}{ NS } & & \multicolumn{2}{|c|}{ NS } & \multicolumn{2}{|c|}{ NS } & \\
\hline
\end{tabular}

Data are mean of 15 orchards each held in separate storage rooms each year. There were ten $\approx 380$-kg samples for each treatment [control, 1 -methylcyclo propene $(1-\mathrm{MCP})]$ for each orchard. The total number of fruit for each treatment in each year was $\approx 469,500$.

Average followed by same letter in each column are not different by Tukey test $(P<0.05)$.

NS, ***,***Nonsignificant or significant at $P<0.05,0.01$, or 0.001 , respectively. 
Table 2. Incidence (\%) of fungal decay and physiological disorders on 'Fuji' apple fruit after controlled atmosphere storage. Fruit were assessed $24 \mathrm{~h}$ after removal from storage.

\begin{tabular}{|c|c|c|c|c|c|c|c|c|c|c|c|}
\hline \multirow[b]{2}{*}{ Yr } & \multicolumn{2}{|c|}{ Fungal decay } & \multicolumn{2}{|c|}{ Superficial Scald } & \multicolumn{2}{|c|}{ Shrivel } & \multicolumn{3}{|c|}{ Ca-deficiency disorders } & \multicolumn{2}{|c|}{ Total } \\
\hline & Control & 1-MCP & Control & 1-МCP & Control & 1-MCP & Control & 1-MCP & Avg & Control & 1-MCP \\
\hline 2007 & 7.2 & 6.2 & 1.25 & 0.02 & 0.5 & 0.4 & 0.68 & 0.37 & $0.53 \mathrm{~b}$ & 9.7 & 7.0 \\
\hline 2008 & 5.2 & 5.3 & 0.92 & 0.03 & 0.6 & 0.4 & 0.49 & 0.41 & $0.45 \mathrm{~b}$ & 7.3 & 6.2 \\
\hline 2010 & 6.0 & 5.0 & 1.71 & 0.23 & 0.4 & 0.2 & 0.38 & 0.33 & $0.35 \mathrm{~b}$ & 8.4 & 5.8 \\
\hline Average & 6.3 & 5.6 & 1.01 & 0.07 & 0.4 & 0.3 & 0.61 & 0.57 & & 8.4 & 6.6 \\
\hline
\end{tabular}

Data are mean of 17 orchards each held in separate storage rooms each year. There were ten $\approx 400-\mathrm{kg}$ samples for each treatment [control, 1-methylcyclo propene (1-MCP)] for each orchard. The total number of fruit for each treatment in each year was $\approx 502,010$.

Average followed by same letter in each column are not different by Tukey test $(P<0.05)$.

Ns, * **,***Nonsignificant or significant at $P<0.05,0.01$, or 0.001 , respectively.

Table 3. Incidence (\%) of fungal decay and physiological disorders on 'Gala' apple fruit after $7 \mathrm{~d}$ at $22^{\circ} \mathrm{C}$ following controlled atmosphere storage.

\begin{tabular}{|c|c|c|c|c|c|c|c|c|c|c|c|}
\hline \multirow[b]{2}{*}{ Yr } & \multicolumn{3}{|c|}{ Fungal decay } & \multicolumn{3}{|c|}{ Ca-deficiency disorders } & \multicolumn{2}{|c|}{ Shrivel } & \multicolumn{3}{|c|}{ Flesh browning } \\
\hline & Control & 1-МCP & Avg & Control & 1-МCP & Avg & Control & 1-MCP & Control & 1-МCP & Avg \\
\hline 2007 & 19.0 & 16.3 & $17.6 \mathrm{a}$ & 0.00 & 0.00 & $0.00 \mathrm{~b}$ & 0.20 & 0.02 & 14.2 & 12.3 & $13.3 \mathrm{a}$ \\
\hline 2008 & 8.1 & 8.7 & $8.4 \mathrm{~b}$ & 0.10 & 0.20 & $0.15 \mathrm{ab}$ & 0.00 & 0.12 & 8.6 & 8.0 & $8.3 \mathrm{ab}$ \\
\hline 2010 & 18.6 & 15.7 & $17.1 \mathrm{a}$ & 0.40 & 0.50 & $0.44 \mathrm{ab}$ & 1.72 & 1.04 & 15.0 & 11.5 & $13.3 \mathrm{a}$ \\
\hline Average & 14.0 & 12.3 & & 0.28 & 0.28 & & 0.57 & 0.31 & 11.5 & 9.2 & \\
\hline
\end{tabular}

Data are mean of 15 orchards each held in separate storage rooms each year. There were ten 100-fruit samples for each treatment [control, 1-methylcyclo propene (1-MCP)] for each orchard. The total number of fruit for each treatment in each year was 15,000 .

Average followed by same letter in each column are not different by Tukey test $(P<0.05)$.

Ns, $* * *, * *$ Nonsignificant or significant at $P<0.05,0.01$, or 0.001 , respectively.

$\mathrm{CO}_{2}$ injury incidence was highest in 2007 and was enhanced by 1-MCP treatment.

The relative loss (\%) of apple fruit by decay and physiological disorders increased during the shelf-life period compared with during CA storage for both cultivars, regardless of 1-MCP treatment.

In addition to the observed higher incidence of decay after shelf life, the variability among orchards due to decay was greater after shelf life (Fig. 1E and F) than after CA storage (Fig. 1C and D). In 2007, 'Gala' losses due to decay during shelf life varied from $6.3 \%$ to $24 \%$ for $50 \%$ of the orchards, and between $2.8 \%$ and $39.7 \%$ for $90 \%$ of the orchards, whereas in 2009, 'Gala' losses due to decay during shelf life varied from $1.6 \%$ to $5.3 \%$ for $50 \%$ of the orchards, and between $0.6 \%$ and $30.5 \%$ for $90 \%$ of the orchards (Fig. 1E). In 2010 , 'Fuji' losses due to decay varied from $16 \%$ to $35.6 \%$ for $50 \%$ of the orchards, and between $15 \%$ and $46.4 \%$ for $90 \%$ of the orchards, whereas in 2009, 'Fuji' losses due to fungal decay varied from $6.6 \%$ to $16.8 \%$ for $50 \%$ of the orchards and between $2.6 \%$ and $22.2 \%$ for $90 \%$ of the orchards (Fig. 1F).

\section{Flesh firmness}

Flesh firmness of 'Gala' at harvest and after storage was lowest in 2007 and was equal in fruit harvested in 2008, 2009 and 2010 (Table 5). Flesh firmness of 'Fuji' at harvest and after storage was lowest in 2010 and was equal in fruit harvested in 2007, 2008 and 2009. Fruit treated with 1-MCP had higher flesh firmness for both cultivars after CA storage plus shelf life compared with untreated fruit.

A significant negative correlation existed between flesh firmness and the incidence of flesh browning in 'Gala', regardless of year, and between flesh firmness and fungal decay in 3 of 4 years for 'Gala' and in 2 of 4 years for 'Fuji' (Table 6). Flesh firmness after storage was positively correlated with incidence of superficial scald in 1 of 4 years.

\section{Weather data}

Accumulated rainfall was highest from bloom to harvest of 'Fuji' of 2010 (Table 7). During the last 2 months of fruit growth, the rainfall was $53 \%$ to $84 \%$ higher in 2010 than in the other 3 harvest years for 'Fuji' and $47 \%$ to $33 \%$ higher in 2010 than in 2007 and 2008 for 'Gala'. The relative humidity was slightly lower $(2 \%$ to $6 \%)$ from bloom to harvest of 2007 and 2008 in comparison with the same period of 2010 harvest. The relative humidity during last 2 months of 'Fuji' fruit growth was $7 \%$ lower in 2009 than in 2010. The mean temperature from bloom to harvest was 1.2 to $1.6^{\circ} \mathrm{C}$ higher in 2007 and 2010 than in the 2008 and 2009 . The number of hours with temperatures below $7.2^{\circ} \mathrm{C}$ in the winters preceding growing seasons in 2008, 2009, and
2010 were similarly higher $(\approx 20 \%)$ than in the winter preceding the growing season in 2007.

\section{Fungi associated with decay symptoms in apples}

There was a significant interaction between cultivar and symptom-based identification of pathogens (Table 8). Major diseases in order of decreasing prevalence were bull's-eye rot (Neofabraea sp.), blue mold (Penicillium sp.), gray mold (Botrytis sp.), alternaria $\operatorname{rot}$ (Alternaria sp.), core $\operatorname{rot}$ (Alternaria sp., Fusarium sp.), bitter rot (Glomerella cingulata), white rot (Botryosphaeria sp.), and rhizopus rot (Rhizopus sp.). The incidence of gray mold and moldy core rot were higher in 'Fuji' compared with 'Gala'.

\section{Discussion}

\section{Postharvest losses of 'Gala' and 'Fuji' apples during storage and shelf life}

Food losses have been estimated to reach $\approx 3 \%, 1 \%$, and $12 \%$, during storage, packing, and retail, respectively (Porat et al., 2018). However, the current study shows that apple losses can be higher at these steps along a simulated supply chain in Brazil. The apple losses ranged from $18.3 \%$ to $26.6 \%$, considering the 4-year mean for all physiological disorders and fungal decay during CA storage, plus the fungal decay during shelf life. In Brazil, $\approx 1$ million cubic tons of 'Gala' and 'Fuji' apples are harvested annually, and 
$\approx 50 \%$ of this production is stored for periods longer than $150 \mathrm{~d}$. On the basis of the results of this study, $\approx 91,500$ to 133,000 cubic tons of long-term storage apples could be lost annually during storage and shelf life. The results highlight the potential economic impact of postharvest apple fruit losses.
Few estimates of postharvest apple losses in large-scale trials under commercial condition have been published. A study conducted in Australia showed average losses during storage of $7.5 \%$ due to postharvest injuries and $6.2 \%$ from fungal decay, although the magnitude of the loss varied with apple

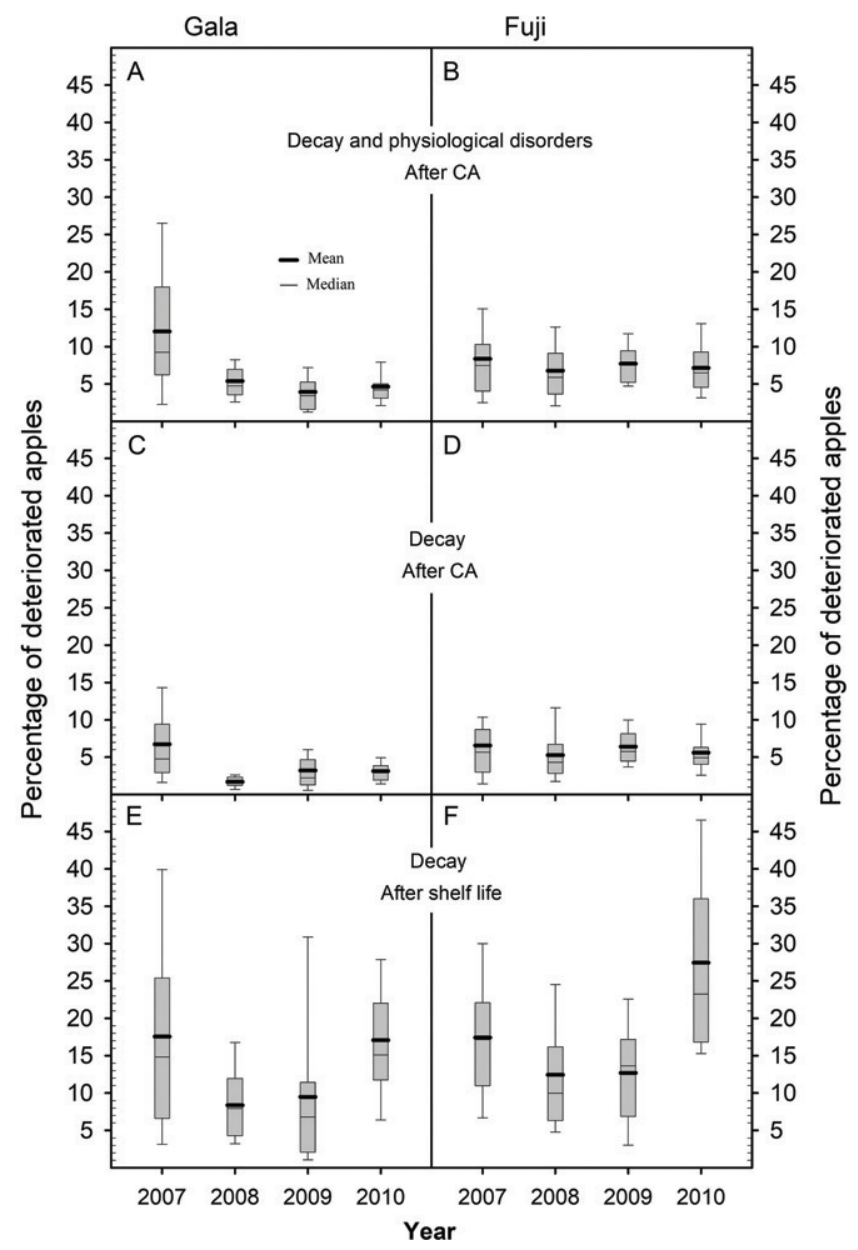

Fig. 1. Variability of deteriorated apple incidence (\%) among orchards (storage rooms) for each cultivar and year. Fruit were assessed for fungal decay and physiological disorders after removal from controlled atmosphere (CA) storage rooms (A-D) and after 7 additional days of shelf life at $22^{\circ} \mathrm{C}(\mathbf{E}, \mathbf{F})$. Fruit loss by fungal decay plus physiological disorders during CA storage $(\mathbf{A}, \mathbf{B})$, for fungal decay during $\mathrm{CA}$ storage $(\mathbf{C}, \mathbf{D})$ and for fungal decay after $7 \mathrm{~d}$ of shelf life at $22^{\circ} \mathrm{C}$ following CA storage $(\mathbf{E}, \mathbf{F})$. For $50 \%$ of orchards (storage rooms) the incidence (\%) of deteriorated apples is in the range of vertical box (25th and 75th percentile of orchards). For $90 \%$ of orchards, the incidence of deteriorated apples is between the down and upper boundary of error bars (10th and 90th percentiles). The thick and thin cross line in the box are the means and medians (\%) of deteriorated apples, respectively. Data of treated and untreated fruit with 1-MCP were averaged for these analyses. variety, orchard, time in storage and handling method (Holmes, 1990). In Washington State (USA), the average apple losses by decay during storage was estimated at $1.9 \%$ and $5.1 \%$ for fruit treated and untreated with postharvest fungicide, respectively (Kim and Xiao, 2008). A survey of refrigerated stores with 'Cox's Orange Pippin' apples in England during four seasons showed that about $6 \%$ of the stored crop was lost during storage and about half of the loss was due to fungal rots (Preece, 1967). On the other hand, many studies conducted under controlled laboratory conditions have shown potential losses of $0 \%$ to $20 \%$ (Colgan and Johnson, 1998; DeEll and Ehsani-Moghaddam, 2013; Gago et al., 2015; Neuwald and Kittemann, 2016) and $0 \%$ to more than $50 \%$ (Breeyen et al., 2020; Cameldi et al., 2016; Neri et al., 2009) due to fungal decay, and from $0 \%$ to more than $50 \%$ by physiological disorders such as superficial scald (DeEll and Ehsani-Moghaddam, 2013; DeLong et al., 2004), bitter pit (Gago et al., 2015; Mattheis et al., 2017), and senescence disorders (Lee et al., 2016), depending on pre- and postharvest experimental treatment.

Although in our study retail conditions were simulated by exposing apples to $22^{\circ} \mathrm{C}$ for $7 \mathrm{~d}$ after CA storage, a previous study conducted under commercial conditions showed 'Gala' and 'Fuji' apples have an average shelf-life period of 17 and $28 \mathrm{~d}$, respectively (Argenta et al., 2015). According to this study, after CA storage, apples are held in cold rooms at packing houses and distribution centers, as well as in trucks during transportation, and eventually in market displays (Argenta et al., 2015). Additionally, apples at retail in Brazil are displayed at a wide range of temperatures (Argenta et al., 2015). Therefore, the incidence of apple losses in our study could be an underestimate, considering the possible combinations of time and temperature that apples are exposed to after long-term storage under commercial conditions. Increasing incidence of decay (Neri et al., 2009) and physiological disorders (Koushesh Saba and Watkins, 2020; Lee et al., 2016) during shelf life after cold storage is presumably due to increased temperature and advanced fruit ripening. Relatively warm temperature during shelf life $\left(15\right.$ to $\left.25^{\circ} \mathrm{C}\right)$ following cold storage favor fungal growth (Adaskaveg et al., 2002) and enhance ethylene

Table 4. Incidence (\%) of fungal decay and physiological disorders on 'Fuji' apple fruit after $7 \mathrm{~d}$ at $22^{\circ} \mathrm{C}$ following controlled atmosphere storage.

\begin{tabular}{|c|c|c|c|c|c|c|c|c|c|c|c|c|c|c|c|c|c|c|c|}
\hline \multirow[b]{2}{*}{ Yr } & \multicolumn{3}{|c|}{ Fungal decay } & \multicolumn{2}{|c|}{ Superficial scald } & \multicolumn{2}{|c|}{ Core rot } & \multicolumn{3}{|c|}{ Shrivel } & \multicolumn{3}{|c|}{$\mathrm{Ca}$ deficiency disorders } & \multicolumn{3}{|c|}{ Core Browning } & \multicolumn{3}{|c|}{$\mathrm{CO}_{2}$ Injury } \\
\hline & C & M & Avg & C & M & C & M & C & M & Avg & C & M & Avg & C & M & Avg & C & M & Avg \\
\hline 2007 & 16.1 & 18.8 & $17.5 \mathrm{~b}$ & 9.3 & 0.6 & 1.7 & 1.9 & 0.6 & 0.3 & $0.4 \mathrm{~b}$ & 0.0 & 0.0 & $0.0 \mathrm{~b}$ & 0.4 & 0.2 & $0.3 \mathrm{~b}$ & 1.9 & 3.0 & $2.4 \mathrm{a}$ \\
\hline 2008 & 10.7 & 14.1 & $12.4 \mathrm{~b}$ & 15.8 & 0.8 & 1.8 & 1.8 & 0.4 & 0.2 & $0.3 \mathrm{~b}$ & 0.3 & 0.4 & $0.3 \mathrm{~b}$ & 1.0 & 0.3 & $0.7 \mathrm{~b}$ & 0.5 & 1.6 & $1.1 \mathrm{~b}$ \\
\hline 2010 & 27.3 & 27.1 & $27.2 \mathrm{a}$ & 17.4 & 0.9 & 2.2 & 3.0 & 3.8 & 1.3 & $2.6 \mathrm{a}$ & 1.6 & 1.1 & $1.4 \mathrm{a}$ & 8.6 & 4.9 & $6.7 \mathrm{a}$ & 0.2 & 1.1 & $0.6 \mathrm{~b}$ \\
\hline Average & 16.5 & 18.4 & & 12.7 & 0.7 & 1.8 & 2.1 & 1.3 & 0.5 & & 0.6 & 0.4 & & 3.4 & 1.4 & & 0.8 & 1.5 & \\
\hline
\end{tabular}

Data are mean of 17 orchards each held in separate storage rooms each year. There were ten 100-fruit samples for each treatment [control (C), 1-methylcyclopropene (M)] for each orchard. The total number of fruit for each treatment in each year was 17,000.

Average followed by same letter in each column are not different by Tukey test $(P<0.05)$.

NS, *,**,**Nonsignificant or significant at $P<0.05,0.01$, or 0.001 , respectively. 


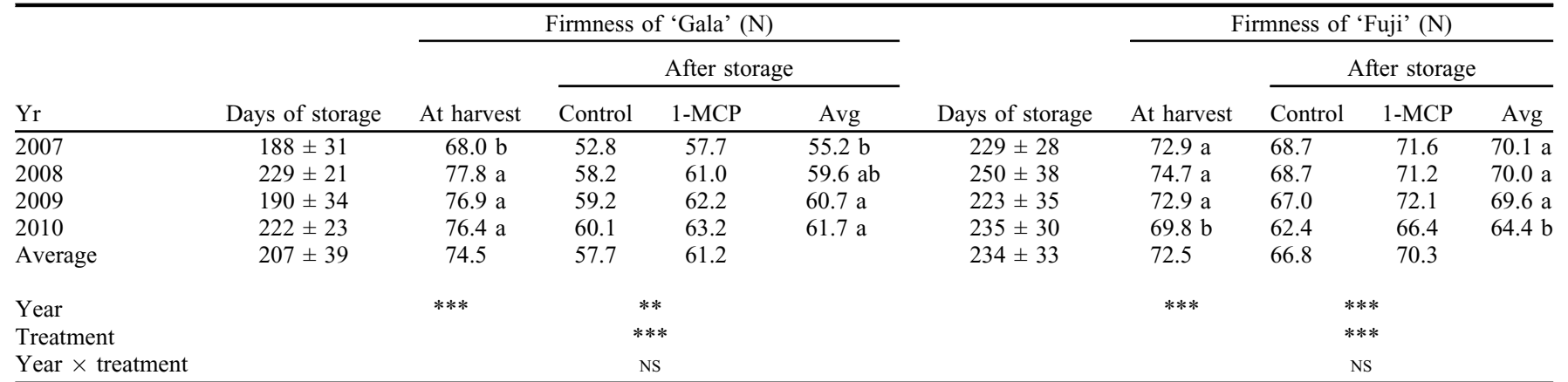

Data are mean of 15 (for 'Gala') and 17 (for 'Fuji') orchards each year. There were twenty 10-fruit samples for each orchard at harvest and ten 100-fruit samples for each treatment [control, 1-methylcyclopropene (1-MCP)] for each orchard after storage.

Average followed by same letter in each column are not different by Tukey test $(P<0.05)$.

Ns, *,*,***Nonsignificant or significant at $P<0.05,0.01$, or 0.001 , respectively.

Table 6. Pearson correlation coefficient among flesh firmness and incidence of fruit affected by major disorders for each cultivar and year, after shelf life. Data of treated and untreated fruit with 1methylcyclopropene were averaged for these analyses.

\begin{tabular}{|c|c|c|c|c|}
\hline \multirow[b]{2}{*}{ Harvest season } & \multicolumn{2}{|c|}{ Gala } & \multicolumn{2}{|c|}{ Fuji } \\
\hline & Fungal decay & Flesh browning & Fungal decay & Superficial scald \\
\hline 2007 & $-0.43 * *$ & $-0.71 * * *$ & $-0.15 \mathrm{NS}$ & $0.12 \mathrm{NS}$ \\
\hline 2008 & $-0.39 *$ & $-0.77 * * *$ & $-0.34 *$ & $0.09 \mathrm{NS}$ \\
\hline 2009 & $-0.29 \mathrm{NS}$ & $-0.42 * *$ & $-0.11 \mathrm{NS}$ & $0.13 \mathrm{NS}$ \\
\hline 2010 & $-0.64 * * *$ & $-0.42 * *$ & $-0.47^{*}$ & $0.40^{*}$ \\
\hline
\end{tabular}

Table 7. Rainfall, relative humidity, and temperature along the fruit growing season and cumulated hours with temperatures below $7.2^{\circ} \mathrm{C}$ along the winter, before the fruit growing season.

\begin{tabular}{llcccc}
\hline & & \multicolumn{3}{c}{ Harvest yr } \\
\cline { 2 - 5 } Variable & Season period & 2007 & 2008 & 2009 & 2010 \\
\hline Accumulated rainfall $(\mathrm{mm})^{\mathrm{z}}$ & During 2 mo. before harvest of Gala & 261 & 209 & 367 & 390 \\
& During 2 mo. before harvest of Fuji & 222 & 226 & 76 & 481 \\
& From bloom to harvest of Gala & 742 & 766 & 896 & 844 \\
& From bloom to harvest of Fuji & 964 & 991 & 972 & 1325 \\
Relative humidity $(\%)^{\mathrm{z}}$ & During two mo. before harvest of Gala & 77.0 & 81.0 & 83.0 & 82.5 \\
& During two mo. before harvest of Fuji & 82.0 & 82.0 & 78.5 & 83.0 \\
& From bloom to harvest of Gala & 76.0 & 77.2 & 80.6 & 78.4 \\
Mean temperature $\left({ }^{\circ} \mathrm{C}\right)^{\mathrm{z}}$ & From bloom to harvest of Fuji & 76.8 & 77.7 & 80.7 & 79.3 \\
& From bloom to harvest of Gala & 20.3 & 19.1 & 18.8 & 20.4 \\
Hours below $7.2{ }^{\circ} \mathrm{C}$ & From bloom to harvest of Fuji & 20.5 & 19.1 & 19.0 & 20.2 \\
& Winter & 446 & 564 & 572 & 539 \\
\hline
\end{tabular}

${ }^{\mathrm{z}}$ Including the harvest window period.

The full bloom was early October for both cultivars and the harvest windows were in February for 'Gala' and late March and early April for 'Fuji'.

production, ripening and eventually senescence of apples (DeEll et al., 2007; Lee et al., 2016), while resistance to fungal decay decreases as fruit begin to ripen and senesce (Neri et al., 2019; Nybom et al., 2020; Prusky et al., 2013).

Fungal decay was the major cause of postharvest losses and the incidence increased during shelf life as reported previously (Neri et al., 2009). This result reinforces the importance of maintaining the cold chain to prevent qualitative and quantitative losses of apples after CA storage and agrees with previous studies suggesting that apple deterioration from packing to supermarket display is mainly due to decay and bruising (Argenta et al., 2015).

In our study, apple losses were highly variable across years, especially for 'Gala', as well as among orchards (storage rooms) in each year, as previously reported for decay incidence in apples and pears (Breeyen et al., 2020; Kim and Xiao, 2008; Lennox et al., 2003). The variability of apple loss among years may be in part associated with seasonal variability in environmental conditions that can impact pathogen infection in the field (Adaskaveg et al., 2002; Sholberg and Conway, 2016; Spotts et al., 2009; Sugar, 2002). According to these previous reports, winter temperatures can affect the amount of inoculum during the following growing season; high rainfall favors sporulation and dispersion of fungal propagules to the fruit; fungal propagules adhere more strongly to wet surfaces of flowers and fruit, increasing probability of fruit infection; rainfall can affect fruit growth and the integrity of the cuticle as a barrier to fungal infection, as well as the amount of fungicide residue that remains on the fruit surface; fungus survival on fruit surfaces is reduced by higher solar radiation; and most pathogens generally grow best at 20 to $25^{\circ} \mathrm{C}$. Therefore, the higher fungal decay incidence observed after shelf life of both apple cultivars in 2010 is consistent with the higher rainfall observed during fruit growth and development in the same year (Table 8). In addition, the higher incidence of decay observed in 'Gala' apples in 2007 and 2010 , after shelf life, could be associated with higher temperatures during the growing season. However, the highest incidence of fungal decay observed in 'Gala' apples in 2007 was possibly not related to rainfall, but could be associated with lower flesh firmness at harvest and after storage as well as with less chilling temperatures during the winter. The observed higher incidence of senescent breakdown and flesh browning in 'Gala' in 2007 could also be associated with advanced maturity, shown by the lower flesh firmness at harvest.

The observed high variability in fruit losses among orchards each year is likely the result of combined effects due to pre- and postharvest factors such as harvest maturity, orchard management practices and storage duration. Postharvest conditions such as storage temperature and atmosphere $\left(\mathrm{pO}_{2}\right.$ and $\left.\mathrm{pCO}_{2}\right)$ were equal for all fruit of the same cultivar each year. In addition, no fungicide or sanitizer treatments were applied after harvest. Therefore, the main postharvest factor that may have accounted for the observed high variability in fruit losses among orchards was possibly the storage duration as increased storage duration can increase the opportunity for postharvest infection and fungal development in the fruit (Kim and Xiao, 2006; Neri et al., 2009).

The correlation analyses also suggest that the variability among orchards regarding the incidence of major disorders was associated with fruit firmness after storage, particularly for 'Gala'. Considering that fruit from different orchards were stored under the same conditions, the flesh firmness observed after storage is the result of combined effects of harvest maturity, storage duration, and preharvest factors that can affect fruit softening such as size and mineral content (DeEll et al., 2001). Higher incidence of decay in fruit samples with lower firmness (advanced 
Table 8. Relative incidence (\%) of fungus causing decay symptom in 'Gala' and 'Fuji' apples after controlled atmosphere storage.

\begin{tabular}{|c|c|c|c|c|}
\hline Decay & Fungus & Gala & Fuji & Cultivar \\
\hline Bull's-eye rot & Neofabraea sp. & $51.6 \mathrm{a}$ & $42.1 \mathrm{a}$ & NS \\
\hline Blue mold & Penicillium sp. & $27.5 \mathrm{~b}$ & $24.6 \mathrm{~b}$ & NS \\
\hline Gray mold & Botrytis sp. & $9.1 \mathrm{c}$ & $18.3 \mathrm{bc}$ & $*$ \\
\hline Alternaria rot & Alternaria sp. & $10.2 \mathrm{c}$ & $5.2 \mathrm{de}$ & NS \\
\hline Moldy core rot & $\begin{array}{l}\text { Alternaria sp. } \\
\text { Fusarium sp. }\end{array}$ & $0.1 \mathrm{~d}$ & $8.7 \mathrm{~cd}$ & $* * *$ \\
\hline Bitter rot & Glomerella cingulata & $0.8 \mathrm{~d}$ & $1.0 \mathrm{ef}$ & NS \\
\hline White rot & Botryosphaeria sp. & $0.7 \mathrm{~d}$ & $0.2 \mathrm{ef}$ & NS \\
\hline Rhizopus rot & Rhizopus sp. & $0.1 \mathrm{~d}$ & $0.1 \mathrm{f}$ & NS \\
\hline Cultivar & \multicolumn{4}{|c|}{$*$} \\
\hline Decay & \multicolumn{4}{|c|}{$* * *$} \\
\hline Cultivar $\times$ decay & \multicolumn{4}{|c|}{$* * *$} \\
\hline
\end{tabular}

Average followed by same letter in each column are not different by Tukey test $(P<0.05)$.

NS, $* * *, * * *$ Nonsignificant or significant at $P<0.05,0.01$, or 0.001 , respectively.

ripening) is possibly due to the reduction of fruit phenolic compounds and increasing cell wall breakdown that make the fruit more susceptible to pathogen growth and development (Nybom et al., 2020; Prusky et al., 2013; Sugar, 2002).

The variability in apple losses due to decay among orchards is possibly related to preharvest crop management and environmental conditions. Postharvest decay susceptibility is determined by a number of factors including tree age, preharvest disease control, pruning, nutrient management, weed control, fruit thinning, handling during harvest, and orchard sanitation (Cameldi et al., 2016; Lennox et al., 2003; Spotts et al., 2009; Sugar et al., 2003; Valdebenito-Sanhueza et al., 2010). Preharvest calcium sprays can decrease, whereas excessive nitrogen fertilization can increase susceptibility of apple fruit to fungal decay (Fallahi et al., 1997; Sugar et al., 2003). Similarly, tree and fruit nutrition in the field as well as cultural practices are potential causes of seasonal and orchard variability on fruit losses by physiological disorders (Watkins and Mattheis, 2019).

Fruit treated with 1-MCP maintained higher flesh firmness and had reduced incidence of superficial scald, flesh browning, and shrivel during and after long-term storage. However, 1-MCP had no effect on pathogen decay incidence after storage and shelf life. Indeed, the role of 1-MCP in inhibiting decay incidence has been variable. Studies have shown that 1-MCP can reduce decay caused by gray mold, bull's eye rot, and blue mold after apple storage and shelf life (Cameldi et al., 2016; Saftner et al., 2003). Other studies have also shown reduction in the incidence of gray mold, bull's eye and phacidiopycnins rots when Anjou pear fruit were treated with 1-MCP (Spotts et al., 2007). In addition, 'Red Fuji' apples treated with 1MCP showed lower incidence and severity of blue mold, which was suggested to be the result of ethylene biosynthesis inhibition, leading to higher reactive oxygen species production that can inhibit the growth of Penicilium expansum (Li et al., 2017). However, other studies show that 1-MCP increased bitter rot and blue mold decay, which was attributed to the reduction in the activity of phenylalanine ammonia-lyase, the enzyme involved in many defense mechanisms (Janisiewicz et al., 2003).

\section{Fungi causing apple fruit decay}

The most important diseases leading to postharvest losses in both 'Gala' and 'Fuji' apples grown in southern Brazil were bull'seye rot and blue mold, which together reached $79 \%$ and $67 \%$ of the total decayed apples, respectively. However, bull's-eye rot was the most frequent cause of decay incidence, reaching $51.6 \%$ and $42.1 \%$ of total decayed fruit in 'Gala' and 'Fuji', respectively. Indeed, bull's eye rot has been reported to be a major disease in apples around the world (Breeyen et al., 2020; Cameldi et al., 2016; Nybom et al., 2016; Valdebenito-Sanhueza et al., 2010; Wenneker et al., 2016). The incidence of blue mold was higher in 'Fuji' than in 'Gala', whereas the incidence of alternaria rot was higher in 'Gala' than in 'Fuji', showing that depending on the disease, the resistance response of each cultivar can be different. Accordingly, studies have shown that a cultivar highly resistant to one pathogen can be highly susceptible to other pathogens (Spotts et al., 1999).

Although total fungal decay incidence results are similar to those previously reported from other apple production regions, the results for individual pathogens are different from other studies possibly due to different interactions among pathogen, host, and environmental conditions, which determines pathogen infection before harvest. Penicillium spp., Botrytis cinerea, Sphaeropsis pyriputrescens, and Neofabraea spp. accounted for $32 \%, 28 \%, 17 \%$, and $13.4 \%$ of decayed apples, respectively, and Alternaria spp., Mucor piriformis, and Phacidiopycnis washingtonensis were less frequent causes of postharvest decay in Washington State (Kim and Xiao, 2008). The most common pathogens causing postharvest decay in apples have been reported to be Penicillium spp. (29\% incidence), Botrytis cinera (25\%), Mucor spp. (22\%), and Neofabraea spp. (10.5\%) in Canada (Sholberg and Haag, 1996) and Neofabraea spp. (62\%), Botrytis cinerea $(30 \%)$, and Colletotrichum acutatum ( $8 \%$ ) in the Nordic region of Europe (Nybom et al., 2016). In northern Greece, the most important pathogens leading to postharvest losses in 'Fuji' apples were Penicillium expansum, Alternaria sp., and Botrytis cinerea (Konstantinou et al., 2011). In the Netherlands, the most important apple pathogen has been reported to be Neofabraea alba, followed by Botrytis spp., Pencillium spp., Fusarium spp., Alternaria spp., and Cladosporium spp. (Wenneker et al., 2016). The most abundant fungi causing decay in 'Nicoter' apples grown in Belgium was Penicillium spp., followed by Fusarium spp., Botrytis spp., Neonectria spp., and Monilinia spp. (Naets et al., 2020).

In summary, these results identify some limiting factors to long-term storage of apples and suggest future research on developing efficient approaches to reduce losses and improve the efficiency of the whole apple industry. Apple losses during CA storage and shelf life were from $18.3 \%$ to $26.6 \%$ and were highly variable among orchards and production years. Decay accounted for $\approx 60 \%$ to $80 \%$ of total losses of 'Gala' and 'Fuji' apples during storage, respectively. It is known that most decays are triggered by preharvest pathogen infection, which develops later during and after storage when the fruit becomes more susceptible to pathogen growth (Prusky et al., 2013; Wenneker and Thomma, 2020). Hence, although new apple cultivars genetically tolerant or resistant to these pathogens are not available, approaches to reduce apple losses must consider the improvement and adoption of orchard management practices as an integrated system that includes proper orchard management to reduce pathogen reproduction, preharvest treatment with fungicides, orchard sanitation, development of predictive models for determining the incidence of decay that can help in segregating orchards for different storage rooms and storage duration, prevention of fruit wounding, rapid postharvest cooling, and postharvest sanitation treatments (Adaskaveg et al., 2002; Sholberg and Conway, 2016; Spotts et al., 2009). In addition, the observed higher fruit loses due to fungal infection during shelf life highlights the importance of the cold chain following CA storage for reducing fruit losses.

\section{Literature Cited}

Adaskaveg, J.E., H. Förster, and N.F. Sommer. 2002. Principles of postharvest pathology and management of decay of edible horticultural crops, p. 163-195. In: A.A. Kader (ed.). Postharvest technology of horticultural crops. University of California, ANR Publication, Davis, CA.

Argenta, L.C., M.J. Vieira, F.d. Souza, W.S.P. Pereira, and F.K. Edagi. 2015. Diagnóstico da qualidade de maçãs no mercado varejista Brasileiro. Rev. Bras. Frutic. 37:48-63, doi: 10.1590/01 00-2945-047/14

Bai, J., R.K. Prange, and P.M.A. Toivonen. 2009. Pome Fruits, p. 267-286. In: E.M. Yahia (ed.) Modified and controlled atmospheres for the storage, transportation, and packaging of horticultural Commodities. CRC Press Taylor \& Francis Group, Boca Raton, FL. 
Breeyen, A.D., J. Rochefort, A. Russouw, J. Meitz-Hopkins, and C.L. Lennox. 2020. Preharvest detection and postharvest incidence of phlyctema vagabunda on 'Cripps Pink' apples in South Africa. Plant Dis. 104:841-846, doi: 10.1094/PDIS-04-19-0818-RE.

Buzby, J.C., J. Hyman, H. Stewart, and H.F. Wells. 2011. The value of retail- and consumer-level fruit and vegetable losses in the United States. J. Consum. Aff. 45:492-515, doi: 10.1111/j.1745-6606.2011.01214.x.

Cameldi, I., F. Neri, D. Ventrucci, G. Ceredi, E. Muzzi, and M. Mari. 2016. Influence of harvest date on bull's eye rot of 'Cripps Pink' apple and control chemical strategies. Plant Dis. 100: 2287-2293, doi: 10.1094/PDIS-05-16-0615-RE.

Colgan, R.J. and D.S. Johnson. 1998. The effects of postharvest application of surface sterilizing agents on the incidence of fungal rots in stored apples and pears. J. Hort. Sci. Biotechnol. 73: 361-366, doi: 10.1080/14620316.1998.11510986.

DeEll, J. and B. Ehsani-Moghaddam. 2013. Effects of rapid consecutive postharvest 1-methylcyclopropene treatments on fruit quality and storage disorders in apples. HortScience 48:227-232, doi: 10.21273/hortsci.48.2.227.

DeEll, J., D.P. Murr, L. Wiley, and M.D. Porteous. 2003. 1-methylcyclopropene (1-MCP) increases CO2 injury in apples. Acta Hort. 600:277-280, doi: 10.17660/ActaHortic.2003.600.37.

DeEll, J.R., J.T. Ayres, and D.P. Murr. 2007. 1Methylcyclopropene influences 'Empire' and 'Delicious' apple quality during long-term commercial storage. HortTechnology 17:4651, doi: 10.21273/horttech.17.1.46.

DeEll, J.R., S. Khanizadeh, F. Saad, and D.C. Ferree. 2001. Factors affecting apple fruit firmness-a review. J. Amer. Pomol. Soc. 55:8-26.

DeLong, J.M., R.K. Prange, and P.A. Harrison. 2004. The influence of 1-methylcyclopropene on 'Cortland' and 'McIntosh' apple quality following long-term storage. HortScience 39: 1062-1065, doi: 10.21273/hortsci.39.5.1062.

Errampalli, D., L.I. Wainman, and J.R. DeEll. 2012. Reduced risk control options for apple postharvest diseases in long-term storages. Acta Hort. 934:313-318, doi: 10.17660/ActaHortic. 2012.934.39.

Fallahi, E., W.S. Conway, K.D. Hickey, and C.E. Sams. 1997. The role of calcium and nitrogen in postharvest quality and disease resistance of apples. HortScience 32:831-835, doi: 10.21273/ hortsci.32.5.831.

Gago, C.M.L., A.C. Guerreiro, G. Miguel, T. Panagopoulos, C. Sánchez, and M.D.C. Antunes. 2015. Effect of harvest date and 1-MCP (SmartFresh ${ }^{\mathrm{TM}}$ ) treatment on 'Golden Delicious' apple cold storage physiological disorders. Postharvest Biol. Technol. 110:77-85, doi: 10.1016/j.postharvbio.2015.07.018.

Holmes, R. 1990. An analysis of postharvest losses in the Victorian pomefruit industry. Department of Agriculture and Rural Affairs (Australia), Victoria.

Janisiewicz, W.J., B. Leverentz, W.S. Conway, R.A. Saftner, A.N. Reed, and M.J. Camp. 2003. Control of bitter rot and blue mold of apples by integrating heat and antagonist treatments on 1-MCP treated fruit stored under controlled atmosphere conditions. Postharvest Biol. Technol. 29:129-143, doi: 10.1016/s092 5-5214(03)00040-1.

Kader, A.A. 2005. Increasing food availability by reducing postharvest losses of fresh produce. Acta Hort. 682:2169-2176, doi: 10.17660/ ActaHortic.2005.682.296.

Kim, Y.K. and C.L. Xiao. 2006. A postharvest fruit rot in apple caused by Phacidiopycnis washingtonensis. Plant Dis. 90:1376-1381, doi: 10.1094/PD-90-1376.

Kim, Y.K. and C.L. Xiao. 2008. Distribution and incidence of sphaeropsis rot in Apple in Washington State. Plant Dis. 92:940-946, doi: 10.1094/PDIS-92-6-0940.

Konstantinou, S., G.S. Karaoglanidis, G.A. Bardas, I.S. Minas, E. Doukas, and A.N. Markoglou. 2011. Postharvest fruit rots of apple in Greece: Pathogen incidence and relationships between fruit quality parameters, cultivar susceptibility, and patulin production. Plant Dis. 95:666-672, doi: 10.1094/PDIS-11-10-0856.

Koushesh Saba, M. and C.B. Watkins. 2020. Flesh browning development of 'Empire' apple during a shelf life period after 1-methylcyclopropene (1-MCP) treatment and controlled atmosphere storage. Scientia Hort. 261:108938, doi: 10.1016/j.scienta.2019.108938.

Lee, J., J.P. Mattheis, and D.R. Rudell. 2016. Storage temperature and 1-methylcyclopropene treatment affect storage disorders and physiological attributes of 'Royal Gala' apples. HortScience 51:84-93, doi: 10.21273/ hortsci.51.1.84.

Lennox, C.L., R.A. Spotts, and L.A. Cervantes. 2003. Populations of Botrytis cinerea and Penicillium spp. on pear fruit, and in orchards and packinghouses, and their relationship to postharvest decay. Plant Dis. 87:639-644, doi: 10.1094/PDIS.2003.87.6.639.

Leverentz, B., W.S. Conway, W.J. Janisiewicz, R.A. Saftner, and M.J. Camp. 2003. Effect of combining MCP treatment, heat treatment, and biocontrol on the reduction of postharvest decay of 'Golden Delicious' apples. Postharvest Biol. Technol. 27:221-233, doi: 10.1016/ S0925-5214(02)00097-2.

Li, J., H. Lei, H. Song, T. Lai, X. Xu, and X. Shi. 2017. 1-Methylcyclopropene (1-MCP) suppressed postharvest blue mold of apple fruit by inhibiting the growth of Penicillium expansum. Postharvest Biol. Technol. 125:59-64, doi: 10.1016/j.postharvbio.2016.11.005.

Mattheis, J.P. 2008. How 1-methylcyclopropene has altered the Washington State apple industry. HortScience 43:99-101, doi: 10.21273/ hortsci.43.1.99.

Mattheis, J.P., D.R. Rudell, and I. Hanrahan. 2017. Impacts of 1-methylcyclopropene and controlled atmosphere established during conditioning on development of bitter pit in 'Honeycrisp' apples. HortScience 52:132-137, doi: 10.21273/HORTSCI11368-16.

Naets, M., L. Bossuyt, B. De Coninck, W. Keulemans, and A. Geeraerd. 2020. Exploratory study on postharvest pathogens of 'Nicoter' apple in Flanders (Belgium). Scientia Hort. 260: 108872, doi: 10.1016/j.scienta.2019.108872.

Neri, F., L. Cappellin, E. Aprea, F. Biasioli, F. Gasperi, A. Spadoni, I. Cameldi, A. Folchi, and E. Baraldi. 2019. Interplay of apple volatile organic compounds with Neofabraea vagabun$d a$ and other post-harvest pathogens. Plant Pathol. 68:1508-1524, doi: 10.1111/ppa.13072.

Neri, F., M. Mari, S. Brigati, and P. Bertolini. 2009. Control of Neofabraea alba by plant volatile compounds and hot water. Postharvest Biol. Technol. 51:425-430, doi: 10.1016/j. postharvbio.2008.08.006.

Neuwald, D.A. and D. Kittemann. 2016. The incidence of Neofabraea spp. in 'Pinova' apples can be reduced at elevated storage temperatures. Acta Hort. 1144:231-235, doi: 10.17660/ ActaHortic.2016.1144.34.

Nybom, H., M. Ahmadi-Afzadi, K. Rumpunen, and I. Tahir. 2020. Review of the impact of apple fruit ripening, texture and chemical contents on genetically determined susceptibility to storage rots. Plants 9:1-22, doi: 10.3390/ plants9070831.

Nybom, H., D. Roen, S. Karhu, L. Garkava-Gustavsson, I. Tahir, T. Haikonen, K. Roen, M. AhmadiAfzadi, M. Ghasemkhani, J. Sehic, and S.H. Hjeltnes. 2016. Pre-breeding for future challenges in Nordic apples: Susceptibility to fruit tree canker and storage diseases. Acta Hort. 1127:117123, doi: 10.17660/ActaHortic.2016.1127.20.

Pierson, C.F., M.J. Ceponis, and L.P. McColloch. 1971. Market diseases of apples, pears and quinces. U.S. Department of Agriculture-Agricultural Research Service, Washington, DC.

Porat, R., A. Lichter, L.A. Terry, R. Harker, and J. Buzby. 2018. Postharvest losses of fruit and vegetables during retail and in consumers' homes: Quantifications, causes, and means of prevention. Postharvest Biol. Technol. 139:135149, doi: 10.1016/j.postharvbio.2017.11.019.

Preece, T.F. 1967. Losses of 'Cox's orange pippin' apples during refrigerated storage in England, 1961-65: A contribution from the Conference of Advisory Plant Pathologists, National Agricultural Advisory Service. Plant Pathol. 16:176180, doi: 10.1111/j.1365-3059.1967.tb00401.x.

Prusky, D., N. Alkan, T. Mengiste, and R. Fluhr. 2013. Quiescent and necrotrophic lifestyle choice during postharvest disease development. Annu. Rev. Phytopathol. 51:155-176, doi: 10.1146/annurev-phyto-082712-102349.

Saftner, R.A., J.A. Abbott, W.S. Conway, and C.L. Barden. 2003. Effects of 1-methylcyclopropene and heat treatments on ripening and postharvest decay in 'Golden Delicious' apples. J. Amer. Soc. Hort. Sci. 128:120-127, doi: 10.21273/ jashs.128.1.0120.

Sholberg, P.L. and W.S. Conway. 2016. Postharvest pathology, p. 111-127. In: K.C. Gross, C.Y. Wang, and M. Saltveit (eds.). The commercial storage of fruits, vegetables, and florist and nursery stocks. USDA-ARS, Washington, DC.

Sholberg, P.L. and P.D. Haag. 1996. Incidence of postharvest pathogens of stored apples in British Columbia. Can. J. Plant Pathol. 18:81-85, doi: 10.1080/07060669609500661.

Snowdon, A.L. 1990. A colour atlas of post-harvest diseases and disorders of fruits and vegetables. Volume 1: General introduction and fruits. Wolfe Scientific Ltd., London, UK.

Spotts, R.A., L.A. Cervantes, and E.A. Mielke. 1999. Variability in postharvest decay among apple cultivars. Plant Dis. 83:1051-1054, doi: 10.1094/PDIS.1999.83.11.1051.

Spotts, R.A., M. Serdani, K.M. Wallis, M. Walter, T. Harris-Virgin, K. Spotts, D. Sugar, C.L. Xiao, and A. Qu. 2009. At-harvest prediction of grey mould risk in pear fruit in long-term cold storage. Crop Prot. 28:414 420, doi: 10.10 16/j.cropro.2009.01.001.

Spotts, R.A., P.L. Sholberg, P. Randall, M. Serdani, and P.M. Chen. 2007. Effects of 1MCP and hexanal on decay of d'Anjou pear fruit in long-term cold storage. Postharvest Biol. Technol. 44:101-106, doi: 10.1016/j. postharvbio.2006.12.003.

Sugar, D. 2002. Management of postharvest diseases, p. 225-252. In: M. Knee (ed.). Fruit quality and its biological basis. CRC Press, Boca Raton, FL.

Sugar, D., J.M. Benbow, K.A. Powers, and S.R. Basile. 2003. Effects of sequential calcium chloride, ziram, and yeast orchard sprays on postharvest decay of pear. Plant Dis. 87:1260 1262, doi: 10.1094/PDIS.2003.87.10.1260.

Sutton, T.B., J.F. Walgenbach, H.S. Aldwinckle, and A. Agnello. 2014. Compendium of apple 
and pear diseases and pests. The American Phytopathological Society, Saint Paul, MN.

Valdebenito-Sanhueza, R.M., P. Spolti, and E.M. del Ponte. 2010. Control of initial inoculum for reducing losses by bull's eye rot on apples. Rev. Bras. Frutic. 32:1044-1054, doi: 10.1590/ S0100-29452010005000127.

Watkins, C.B. 2008. Overview of 1-methylcyclopropene trials and uses for edible horticultural crops. HortScience 43:86-94, doi: 10.21273/ hortsci.43.1.86
Watkins, C.B. and J.P. Mattheis. 2019. Apple, p. 165-206. In: S.T. de Freitas and S. Pareek (eds.). Postharvest physiological disorders in fruits and vegetables. CRC Press Taylor \& Francis Group, Boca Raton, FL, doi: 10.1201/ b22001.

Wenneker, M., J. Köhl, P. Van Leeuwen, K. Pham, and A. Van Schaik. 2016. Control of postharvest storage rots of apples and pears in the Netherlands. Acta Hort. 1144:189-194, doi: 10.17660/ActaHortic.2016.1144.27.
Wenneker, M. and B.P.H.J. Thomma. 2020. Latent postharvest pathogens of pome fruit and their management: From single measures to a systems intervention approach Eur. J. Plant Pathol. 156:663-681, doi: 10.1007/s10658-020-01935-9.

Zhou, X.W., H.L. Zhou, Y.L. Shi, Y.P. Tang, and N. Meng. 2016. Mechanism of 1-MCP-induced resistance to grey mold in postharvest apples. Mod. Food Sci. Technol. 32:211-219, doi: 10.13982/j.mfst.1673-9078.2016.10.032. 